\title{
YIELD RESPONSE OF A MUSTARD MUTANT VARIETY TO DIFFERENT TIMES OF IRRIGATION
}

\author{
A. J. Mila*, A. A. Sarkar ${ }^{1}$, N. N. Karim ${ }^{1}$ and N. Islam² \\ IWM Division, BARI, Gazipur, Bangladesh
}

Bangladesh is an agricultural country. Different kinds of crops like cereals, pulses, oilseeds, vegetables and fruits are grown here. Among them, mustard is one of the major oil seed crops of Bangladesh that covers $66.22 \%$ of the total oil seed area (BBS 2011). The present area and production of mustard are 2.42 lac ha and 2.22 lac $\mathrm{m}$ ton, respectively. The average yield of mustard in Bangladesh is very low (0.9 t/ha) (BBS 2011) compared to that of other oilseeds growing countries in the world. The reasons of lower yield are lack of good quality mustard seeds, lack of inadequate irrigation water and lack of inadequate adoption of improved production technologies. Bangladesh is producing about 0.16 million tons of edible oil per year against the requirement of 0.5 million tons (Miah and Alam 2009). There has been big gap between supply and demand of edible oils, which has been met through imports incurring a big amount of foreign exchange every year. Single irrigation at the vegetative stage produced higher yield than that of irrigation at flowering, pod formation and seed filling stages (Fateh et al. 2002). Two irrigations, one at pre-sowing and the other either at initiation of branching (40 DAS) or at flowering stage (60 DAS) was statistically at par to 3 to 4 irrigation treatments but was significantly superior to presowing irrigation treatment in terms of growth, yield attributes and yield (Jagdev et al. 2001). They also reported that the consumptive use of water increased but the water use efficiency decreased with increasing number of irrigations. The consumptive use (CU) and crop coefficient value (CCV) increased with increasing irrigation frequency and water use efficiency (WUE) reversely related to irrigation frequency (Das and Roy 2003). The total water use and crop coefficient were higher by using protective irrigation twice to the crop and $0-15 \mathrm{~cm}$ of soil layer was the active root zone for moisture extraction (Roy et al. 2003).

BINA Sarisha-4 is a released variety developed by the Bangladesh Institute of Nuclear Agriculture (BINA). It was developed by mutation breeding technique. Potentiality of BINA Sarisha-4 is very high. Maximum seed yield potential is 2.5 tons/ha (average 2.0 tons/ha). Seed contains $44 \%$ oil with low content of erucic acid. But for the changing climatic condition over time and space, the irrigation demand and yield potentiality of the crop needs to be verified at different agro-ecological Zones of the country. In consideration of the above facts, a study on yield response of a mustard mutant variety, BINA Sarisha-4 to different times of irrigation was undertaken.

The experiment was conducted at the Bangladesh Institute of Nuclear Agriculture (BINA) farm, Mymensingh. The topography of the land is medium high and the soil belongs to the old

*Corresponding author: <afrinbau@gmail.com>. ${ }^{1}$ Agricultural Engineering Division, BINA, Mymensingh, Bangladesh. ${ }^{2}$ Department of IWM, Bangladesh Agricultural University, Mymensingh, Bangladesh. 
Brahmaputra Flood Plain with total N (\%) of 0.067, available P (ppm) of 38.5, K (me \%) of 0.107 and the $\mathrm{pH}$ value of 7.0. The bulk density of the soil ranged from 1.48 to $1.61 \mathrm{gm} / \mathrm{cm}^{3}$ (Sarkar et al.1990). The major climatic parameters of the experimental field viz., the air temperature (20.58 $\left.{ }^{\circ} \mathrm{C}\right)$, humidity (82\%), rainfall $(0 \mathrm{~mm})$, wind speed $(1.08 \mathrm{~km} / \mathrm{h})$, sun shine $(5.89 \mathrm{hrs})$, solar radiation $\left(223 \mathrm{w} / \mathrm{m}^{2}\right)$ and evaporation $(2.27 \mathrm{~mm})$ data were collected from the weather yard of the Department of Irrigation and Water Management of Bangladesh Agricultural University. The experiment was set up in a randomized completely block design with four treatments and three replications. The plot size was $5 \mathrm{~m} \times 4 \mathrm{~m}$. The irrigation treatments were: $\mathrm{I}_{0}$ : No Irrigation (control); $\mathrm{I}_{1}$ : Irrigation at the vegetative stage (32 DAS) up to field capacity (FC), $\mathrm{I}_{2}$ : Irrigation at flowering stage (53 DAS) up to field capacity (FC) and $\mathrm{I}_{3}$ : Irrigation at the vegetative and flowering stages up to field capacity (FC), where, DAS is the days after sowing.

The mustard crop was sown manually on $4^{\text {th }}$ November, 2009. The variety BINA Sarisha- 4 was used and seeds were sown in line at the rate of $6.00 \mathrm{~kg} / \mathrm{ha}$. Prior to sowing, soil was fertilized with per hectare basal dose of $150 \mathrm{~kg} \mathrm{~N}$ as urea, $20 \mathrm{~kg}$ P as TSP, $40 \mathrm{~kg} \mathrm{~K}$ as MoP, $14.4 \mathrm{~kg}$ S as Gypsum. Urea was applied in two equal splits; one at active vegetative stage and the other at flowering stage. Intercultural operation was done in proper time. Irrigation water of known volume was applied in the treatment plots with a hose pipe. Soil moisture was measured using neutron moisture meter as well as gravimetrically at sowing, before and after irrigation, and at harvest. The crop was harvested on 14 February 2010. Data on the crop characters viz. plant height (cm), branch no./plant, number of pods/plant, pod length (cm), seed/pod, 1000 seed weight (g), seed yield ( $\mathrm{t} / \mathrm{ha}$ ), straw yield ( $\mathrm{t} / \mathrm{ha}$ ) were recorded. These data were then analyzed statistically.

The sowing time soil moisture in different treatment plots ranged from 24.6 to $28.9 \%$ by volume at 15 to $60 \mathrm{~cm}$ soil depth. The harvest time soil moisture drastically reduced as there was no rainfall during the whole crop growing periods (Fig. 1).

The effect of irrigation on the yield and yield components of mustard mutant variety, BINA Sarisha-4 is presented in Table 1. Irrigation showed significant effect on plant height, branch number per plant, number of pods per plant, seeds per pod per plant, yield, and straw yield and non-significant effect was found on pod length, and 1000 seed weight. The highest plant height $(78.80 \mathrm{~cm})$ was obtained in treatment $\mathrm{I}_{1}$ followed by $\mathrm{I}_{2}(75.80 \mathrm{~cm})$ and the lowest $(74.13 \mathrm{~cm})$ in $\mathrm{I}_{0}$ (control).

The highest number of branch/plant (2.13) was obtained in the treatment $\mathrm{I}_{2}$ and the lowest (1.67) in treatment $I_{0}$ and $I_{1}$. Similarly, the highest number of pods/plant (52.67) and pod length $(6.72 \mathrm{~cm})$ were obtained in the treatment $\mathrm{I}_{2}$ and the lowest in treatment $\mathrm{I}_{0}$. The number of seeds per pod per plant was highest (26.93) in treatment $\mathrm{I}_{2}$ which was $6 \%$ higher over the control $\left(\mathrm{I}_{0}\right)$; but the number decreased with the increase of the irrigation frequency.

The highest and almost similar 1000 seed weight (3.42 g) was obtained in all treatments except treatment $I_{1}$. The highest straw yield ( $2.68 \mathrm{t} / \mathrm{ha}$ ) was obtained in treatment $\mathrm{I}_{1}$ and the lowest (2.31 t/ha) in treatment $I_{3}$. Irrigation showed significant effect on grain yield of mustard. The highest yield of $1.55 \mathrm{t}$ /ha was obtained in treatment $\mathrm{I}_{1}$ and $\mathrm{I}_{3}$ and lowest yield of $1.24 \mathrm{t} /$ ha was 
obtained in treatment $\mathrm{I}_{0}$ (control). This might be due to the reason of higher soil moisture content in the experimental field.

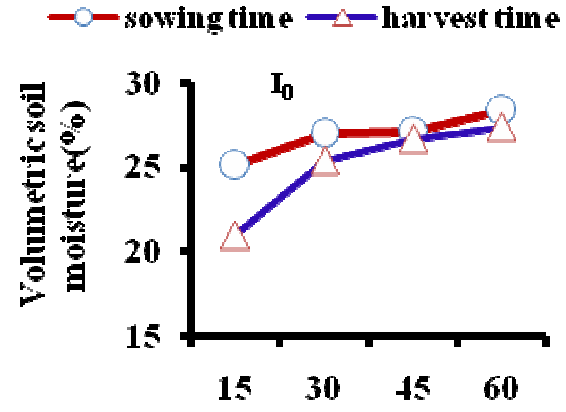

Soil depths (cm)
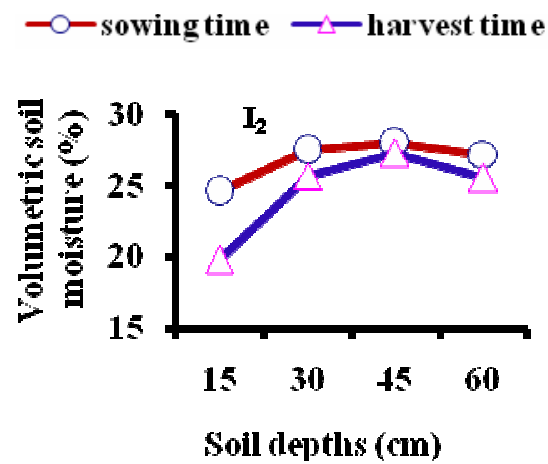

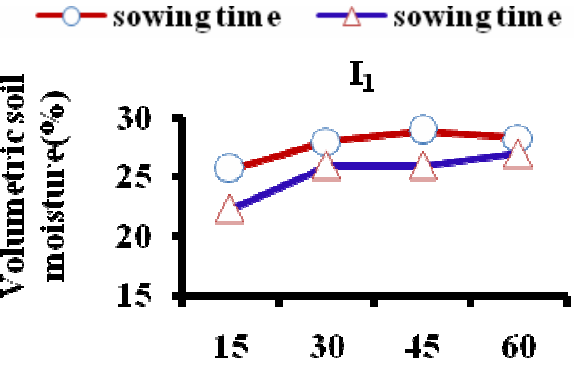

Soll depths (cm)
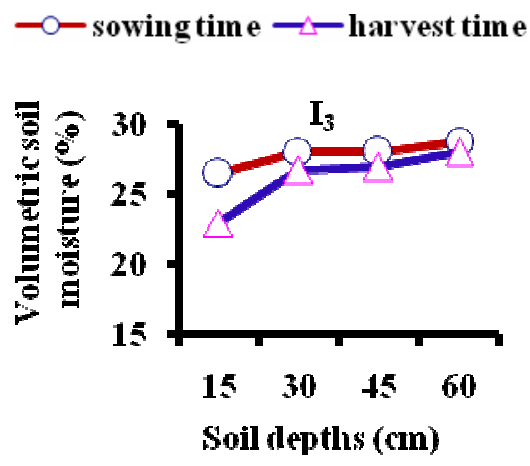

Fig. 1. Sowing and harvest time soil moisture content in the experimental field.

Table 1. Effect of irrigation on the yield and yield components of mustard mutant variety (BINA Sarisha-4).

\begin{tabular}{lcccccccc}
\hline Treatments & $\begin{array}{c}\text { Plant } \\
\text { height } \\
(\mathrm{cm})\end{array}$ & $\begin{array}{c}\text { Branch } \\
\text { no./plant }\end{array}$ & $\begin{array}{c}\text { No. of } \\
\text { pods/ } \\
\text { plant }\end{array}$ & $\begin{array}{c}\text { Pod } \\
\text { length } \\
(\mathrm{cm})\end{array}$ & $\begin{array}{c}\text { Seeds/ } \\
\text { pod /plant }\end{array}$ & $\begin{array}{c}1000 \\
\text { seed wt. } \\
(\mathrm{g})\end{array}$ & $\begin{array}{c}\text { yield } \\
\text { (t/ha) })\end{array}$ & $\begin{array}{c}\text { Straw } \\
\text { yield } \\
\text { (t/ha) }\end{array}$ \\
\hline $\mathrm{I}_{0}$ & 74.13 & 1.67 & 42.87 & 6.07 & 25.33 & 3.42 & 1.24 & 2.43 \\
$\mathrm{I}_{1}$ & 78.80 & 1.67 & 47.93 & 6.27 & 26.27 & 3.41 & 1.55 & 2.68 \\
$\mathrm{I}_{2}$ & 75.80 & 2.13 & 52.67 & 6.72 & 26.93 & 3.42 & 1.26 & 2.63 \\
$\mathrm{I}_{3}$ & 75.47 & 1.80 & 50.33 & 6.22 & 26.00 & 3.42 & 1.55 & 2.31 \\
LSD (\%) & 1.55 & 0.30 & 1.10 & $\mathrm{NS}$ & 0.63 & $\mathrm{NS}$ & 0.17 & 0.20 \\
$\mathrm{CV}(\%)$ & 1.02 & 8.35 & 1.14 & 9.04 & 1.20 & 0.72 & 5.99 & 3.94 \\
\hline
\end{tabular}

The water expense, water use and water productivity of mustard are presented in Table 2. Water expense was zero $(0 \mathrm{~cm})$ in control $\left(\mathrm{I}_{0}\right)$ because of no rainfall and no irrigation. The highest water expense $(6.06 \mathrm{~cm})$ was noted in treatment $\mathrm{I}_{3}$ as there were two irrigations in this treatment. Water expense was calculated by adding the rainfall, and irrigation profile. The water use 
increased with the increase in number of irrigation. Water use or ET was calculated by adding the rainfall, irrigation and profile soil moisture depletion. The highest water use $(7.22 \mathrm{~cm})$ was obtained in treatment $\mathrm{I}_{3}$ and lowest water use $(1.31 \mathrm{~cm})$ was obtained in treatment $\mathrm{I}_{0}$. The highest water productivity $\left(9.47 \mathrm{~kg} / \mathrm{m}^{3}\right)$ was, however, observed in $\mathrm{I}_{0}$, obviously because of no irrigation and rainfall. The water productivity decreased with the increase of irrigation number and it was lowest $\left(2.15 \mathrm{~kg} / \mathrm{m}^{3}\right)$ in treatment $I_{3}$ followed by $\left(3.01 \mathrm{~kg} / \mathrm{m}^{3}\right)$ in treatment $I_{2}$.

Table 2. Water expense, water use and water productivity of the mustard mutant variety (BINA Sarisha-4).

\begin{tabular}{lccccccc}
\hline Treatments & $\begin{array}{c}\text { Rainfall } \\
(\mathrm{cm})\end{array}$ & $\begin{array}{c}\text { Irrigation } \\
(\mathrm{cm})\end{array}$ & $\begin{array}{c}\text { Water } \\
\text { expense } \\
(\mathrm{cm})\end{array}$ & $\begin{array}{c}\text { Soil moisture } \\
\text { contribution } \\
(\mathrm{cm})\end{array}$ & $\begin{array}{c}\text { Water use } \\
(\mathrm{cm})\end{array}$ & $\begin{array}{c}\text { Yield } \\
(\mathrm{t} / \mathrm{ha})\end{array}$ & $\begin{array}{c}\text { Water } \\
\text { productivity } \\
\left(\mathrm{kg} / \mathrm{m}^{3}\right)\end{array}$ \\
\hline $\mathrm{I}_{0}$ & 0 & 0 & 0 & 1.31 & 1.31 & 1.24 & 9.47 \\
$\mathrm{I}_{1}$ & 0 & 0.70 & 0.70 & 1.27 & 1.97 & 1.55 & 7.87 \\
$\mathrm{I}_{2}$ & 0 & 2.82 & 2.82 & 1.36 & 4.18 & 1.26 & 3.01 \\
$\mathrm{I}_{3}$ & 0 & 6.06 & 6.06 & 1.16 & 7.22 & 1.55 & 2.15 \\
\hline
\end{tabular}

The depth of groundwater table during the experimental period (November - February) is shown in Fig. 2. It showed that in November, December up to $1^{\text {st }}$ week of January, WT declined very slowly and then it declined at a fast rate. Thus, from November to January, water table varied from $6.31 \mathrm{~m}$ to $9.18 \mathrm{~m}$ and at harvest time of the crop at the end of February, WT depth was found

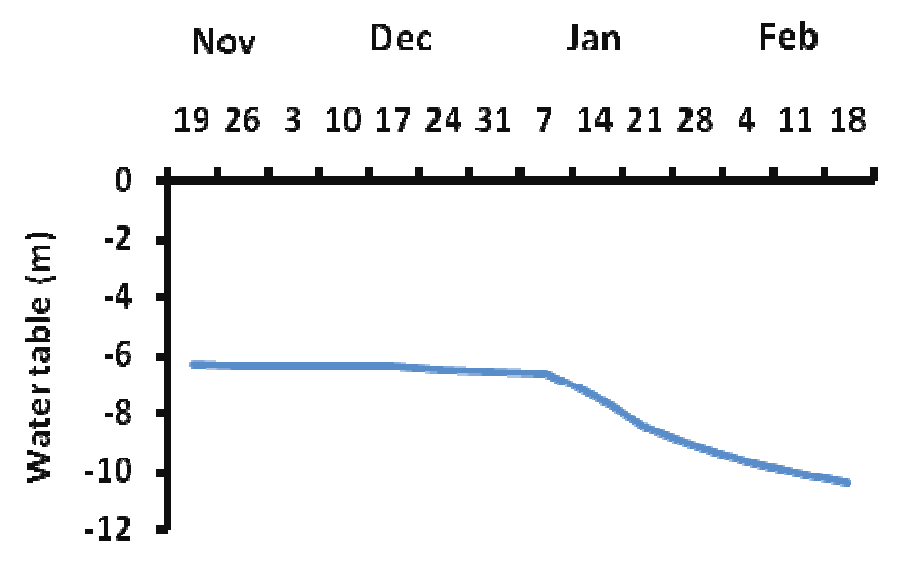

Fig. 2. Water table fluctuation during the experimental period.

to be $10.35 \mathrm{~m}$. This deep water table depth indicated that there might not have any upward flux of water through capillary rise to meet up the ET demand of the crop. Thus, it was evident that the crop fulfilled its water requirement need by the higher residual soil moisture and applied supplemental irrigation at the vegetative stage to produce the optimum yield.

\section{References}


BBS (Bangladesh Bureau of Statistics), 2011. Yearbook of Agricultural Statistics of Bangladesh, Statistics and Information Division, Ministry of planning, Government of the People’s Republic of Bangladesh. Dhaka.

Das, L.K. and M.R. Roy. 2003. Response of different irrigation schedules on consumptive use, water use efficiency and crop co-efficient value of mustard. Environment and Ecology 21(1): 143-145.

Fateh, S., B.S. Sinsinwar, and O.P. Preme. 2002. Effects of irrigation, schedule on the growth, yield and yield contributing characters of Indian mustard. Annals of Agricultural Research 23(3): 411-414.

Jagdev, S., S. Bikram, K. Anil, and J.S. Yadav. 2001. Irrigation scheduling in mustard (Brassica juncea) in light textured soil. Haryana Agricultural University J. of Res. 31(3/4): 99-104.

Miah, M.A.M. and Q.M. Alam. 2009. Adoption and relative profitability of mustard production in Bangladesh. Cited in Research Report 2008-09: Agricultural Economics Division, Bangladesh Agricultural Research Institute, Joydebpur, Gazipur.

Roy, D., P. Bandyopadhyay and P.K. Jana. 2003. Effect of supplemental irrigation on the yield, consumptive use and crop coefficient of Indian mustard (Brassica juncea L.). Indian Agriculturist. 47(1/2): 21-25.

Sarkar, A.A., M. Ahmmed, M.S.U. Talukder and M.R. Khan. 1990. Yield and water use of mustard under different irrigation regimes. Bangladesh J. Agril. Sci. 17(2): 293-298.

(Manuscript received on 3 September, 2013; revised on 23 October, 2013) 